\title{
Пространственно-временные изменения макрофитобентоса бухты Круглая (Черное море)
}

\author{
Наталия В. Миронова (D), Татьяна В. Панкеева \\ Институт биологии южных морей им. А.О. Ковалевского РАН, Севастополь, Россия
}

\section{Контактное лицо}

Наталия В. Миронова, кандидат биологических наук, старший научный сотрудник, отдел биотехнологий и фиторесурсов, Институт биологии южных морей имени А.O.

Ковалевского РАН; 299011 Россия, г. Севастополь, пр. Нахимова, 2. Тел. +79788044819

Email dr.nataliya.mironova@yandex.ru ORCID http://orcid.org/0000-0001-7110 7081

\section{Формат цитирования}

Миронова Н.В., Панкеева Т.В.

Пространственно-временные изменения макрофитобентоса бухты Круглая (Черное море) // Юг России: экология, развитие. 2020. Т.15, N 2. С. 125-139. DOI: 10.18470/1992-10982020-2-125-139

Получена 13 сентября 2019 г. Прошла рецензирование 14 ноября 2019 г. Принята 15 января 2020 г.

\begin{abstract}
Резюме
Цель. Провести сравнительный анализ пространственно-временных изменений макрофитобентоса на основе ландшафтного подхода в бухте Круглая за 40-летний период.

Материал и методы. Подводные исследования бухты Круглая проводили методом детального изучения ключевых участков дна с применением ландшафтного профилирования в летний сезон 1977 и 2018 гг. Ландшафтное картографирование акватории проведено на основе составленных профилей и интерпретационных таблиц.

Результаты. Впервые на основе ландшафтных карт бухты Круглая проведен сравнительный анализ качественных и количественных изменений растительной компоненты ДПк (донный природный комплекс) за более чем 40-летний период.

Заключение. Сравнительный анализ показал, что в составе, структуре и распространении донной растительности отмечены значительные изменения. Для ДПК подводного абразионного склона, сложенного псефитовыми отложениями характерно доминирование видов цистозиры, доля которых снизилась с 76-99 (1977 г.) до 55-92\% (2018г.) общей биомассы макрофитов. Наиболее существенные изменения произошли в ДПК слабонаклонной аккумулятивной равнины, сложенной псаммитово-алевритовыми отложениями, где преобладали морские травы, при этом их вклад составлял 96-99\% общей биомассы макрофитов. Здесь произошла замена зостерового фитоценоза, доминантом которого являлась Zostera marina, а содоминантом Z. noltei, на зостерово-рдестовый фитоценоз, где преобладают Z. noltei и Stuckenia pectinata. Произошедшие перестройки в структуре и составе макрофитобентоса бухты Круглая, вероятно, связаны с влиянием как природных, так и антропогенных факторов.

Ключевые слова

Макрофитобентос, цистозира, филлофора, зостера, донный природный комплекс, бухта Круглая, Черное море.
\end{abstract}

(C) 2020 Авторы. Юг России: экология, развитие. Это статья открытого доступа в соответствии с условиями Сreative Сотmоns Attribution License, которая разрешает использование, распространение и воспроизведение на любом носителе при условии правильного цитирования оригинальной работы. 


\title{
Spatio-temporal changes in the macrophytobenthos of Kruglaya Bay (Black Sea)
}

\author{
Nataliya V. Mironova (iD) and Tatyana V. Pankeeva \\ A.O. Kovalevsky Institute of Biology of the Southern Seas, Russian Academy of Sciences, Sevastopol, Russia
}

\section{Principal contact}

Nataliya V. Mironova, Cand. Sci. (Biol.),

Senior Researcher, A.O. Kovalevsky

Institute of Biology of the Southern Seas,

Russian Academy of Sciences, 2

Nakhimov Ave, Sevastopol, Russia 299011.

Tel. +79788044819

Email dr.nataliya.mironova@yandex.ru ORCID http://orcid.org/0000-0001-7110$\underline{7081}$

\section{How to cite this article}

Mironova N.V., Pankeeva T.V.

Spatiotemporal changes in the

macrophytobenthos of Kruglaya Bay

(Black Sea). South of Russia: ecology,

development. 2020, vol. 15, no. 2, pp.

125-139. (In Russian) DOI:

10.18470/1992-1098-2020-2-125-139

Received 13 September 2019

Revised 14 November 2019

Accepted 15 January 2020

\begin{abstract}
Aim. The aim of the present study is a comparative analysis of spatio-temporal changes in the macrophytobenthos of Kruglaya Bay over a 40-year period (19772018) using a landscape approach.

Material and Methods. Submarine landscape research of Kruglaya Bay was carried out in the summer of 1977 and 2018 by the method of detailed study of the bottom using landscape profiling. The landscape mapping of Kruglaya Bay waters was done based on the constructed profiles and interpretation tables

Results. This research presents for the first time through landscape mapping the results of a comparative analysis of qualitative and quantitative changes in the plant components of BNC (bottom natural complexes) carried out in Kruglaya Bay over a period of more than 40 years.

Conclusions. Comparative analysis showed that the composition, structure and distribution of bottom vegetation have marked significant changes. For the BNC upper shoreface abrasion slope composed of psephitic sediment, the dominance of Cystoseira species (the share of which decreased from 76-99 [1977] to 55-92\% [2018] of the total biomass of macrophytes) is characteristic. The most noticeable changes in the BNC occurred in the gently dipping accumulation plain composed of silt-psammitic sediments, where the dominant community was seagrass throughout the study period with its contribution accounting for $96-99 \%$ of total macrophyte biomass. It was revealed that a change in the Zostera-based phytocoenoses occurred Zostera marina dominating with $Z$. noltei co-dominant to ZosteraStuckenia-based phytocoenoses where $Z$. noltei and Stuckenia pectinata predominate. The changes in the structure and composition of the macrophytobenthos of Kruglaya Bay are probably associated with the influence of both natural and anthropogenic factors.

Key Words

Macrophytes, cystoseira, phyllophora, zostera, bottom natural complexes, Kruglaya Bay, Black Sea.
\end{abstract}

(C) 2020 The authors. South of Russia: ecology, development. This is an open access article under the terms of the Creative Commons Attribution License, which permits use, distribution and reproduction in any medium, provided the original work is properly cited. 


\section{ВВЕДЕНИЕ}

Бухта Круглая отличается биологическим и ландшафтным разнообразием, обилием уникальных местообитаний донной растительности, где представлены фитоценозы как морских трав, так и водорослей. Для бухты характерно наличие краснокнижных видов макрофитобентоса. Известно, что для Черного моря цистозира (Cystoseira barbata C. Ag. и C. crinita (Desf.) Bory), филлофора (Phyllophora crispa (Huds.) P.S. Dixon = Ph. nervosa (DC) Grev.) считаются ключевыми видами водорослей, входят в состав списков Красной книги (КК) Республики Крым (РК) [1] и КК Черного моря [2]. Кроме этого, филлофора внесена в КК РФ [3] и КК Севастополя [4]. Взморники Нольта и морской (Zostera noltei Hornem и Z. marina L.), виды руппии (Ruppia spp.) входят в состав КК РК, при этом сообщества морских трав отнесены ЮНЕП к критическим местообитаниям Мирового океана. Сохранение морских биотопов задекларировано многими природоохранными программами, соглашениями и Конвенциями [5].

Ввиду того, что бухта Круглая имеет высокую созологическую, эстетическую и природоохранную ценность, ее изучению всегда уделялось особое внимание. Впервые бухта описана более 100 лет назад C.A. Зерновым [6], при этом картографические сведения об особенностях распределения основных видов макрофитов приведены в «Карте распределения биоценозов в Черном море у Севастополя» в 1910-1911 гг.

Известна альгологическая работа А.А. Калугиной-Гутник с коллегами [7], выполненная на открытом прибрежье западного мыса бухты Круглая (Омега), где выявлены тенденции в изменениях видового состава и количественном распределении фитобентоса за период с 1964 по 1990 гг. Достаточно полно изучена донная растительность мелководной части бухты Круглая (Омега), где прослежены изменения структуры фитоценозов, видового состава и биомассы макрофитов, входящих в их состав, вдоль береговой линии бухты на глубине 0-0,5 м за период с 1987 по 1997 гг. [8]. В работе С.А. Ковардакова и А.В. Празукина [9] на основе гидроботанических съемок 1989 и 2008 гг. сопоставлены структурные и поточные характеристики фитоценозов внутренней части бухты Круглая, рассчитан самоочистительный потенциал макрофитов, оценены их запасы и потенциальная способность изъятия из воды биогенных элементов и насыщение ее кислородом. В статьях всех авторов показано, что в бухте широко представлены ключевые фитоценозы цистозиры, филлофоры и зостеры.

Приморская и прибрежная зоны бухты отличаются рекреационной привлекательностью. Еще в конце XIX-начале XX вв. на ее берегах строились дачные и курортные поселки. Современное рекреационное природопользование представлено сложным комплексом стационарных объектов (санаторий, детский лагерь, гостиницы и т.д.) и различными видами купально-пляжного отдыха. Однако, активное хозяйственное освоение бухты вызывает ухудшение качества морской среды и приводит к негативным перестройкам В составе и структуре сообществ массовых видов макрофитобентоса.

В современных условиях приобретает актуальность использование ландшафтного подхода при гидроботанических исследованиях. Впервые необходимость применения ландшафтного картографирования для изучения долговременной динамики морских донных сообществ показана в работах Е.Ф. Гурьяновой [10] и Г.У. Линдберг [11]. Согласно мнению К.М. Петрова [12], макрофиты являются индикатором своеобразия морфологических комплексов горизонтального расчленения подводных ландшафтов. Общеизвестно, что донная растительность реагирует на изменения морской среды, что позволяет использовать количественные и качественные показатели макрофитобентоса при изучении ДПк (донный природный комплекс). За последние годы в рамках этого направления выполнено картографирование и проведены исследования пространственно-временных изменений ДПК в регионе Севастополя [13-15].

Цель представленной работы: провести сравнительный анализ пространственно-временных изменений макрофитобентоса на основе ландшафтного подхода в бухте Круглая за 40-летний период (19772018 гг.).

\section{МАТЕРИАЛ И МЕТОДЫ ИССЛЕДОВАНИЯ}

Бухта Круглая (Омега) расположена на северном побережье Гераклейского полуострова между Двойной и Стрелецкой бухтами. Бухта относится к полузакрытому типу, мелководная со средней глубиной 4,5 м [9]. Длина ее береговой линии составляет около 4 км. В северной части бухты подводный склон приглубый, сложен слоистыми сарматскими известняками верхнего миоцена. На глубинах 5-9 м наблюдаются выходы известняков и песчаников в виде плит с гребнями, чередующихся с западинами, частично заполненными мелкообломочным материалом с маломощными гравийными наносами. Южная часть бухты занята слабонаклонной аккумулятивной равниной, сложенной преимущественно песчано-илистыми отложениями, выделяется скалистая отмель с глубинами до 0,5-0,6 м. Кутовая часть бухты ранее являлась лиманом (соленым озером) и была отделена от моря песчаной пересыпью [16]. Сейчас на месте пересыпи существует песчаная отмель с глубиной 1-2 м. Донные осадки представлены илами со значительным количеством обрывков морских трав, водорослей и бытовым мусором [17].

Для изучения пространственно-временных изменений макрофитобентоса с учетом ландшафтной структуры дна использовали материалы двух экспедиций, проведенных в бухте Круглая летом в 1977 и 2018 гг., при этом отбор проб осуществляли по одной и той же методике и на тех же выбранных участках бухты, за исключением разреза IV (рис. 1).

При изучении ландшафтов бухты Круглая использовали общие методологические положения ландшафтоведения и известные методы исследования подводных ландшафтов [14; 15]. Работы проводили с борта маломерного судна с применением легководолазной техники. В бухте заложены восемь ландшафтных профилей (разрезов), которые расположены перпендикулярно к берегу и охватывали все типы ландшафтов (рис. 1; табл. 1). Их длина варьировала в зависимости от особенностей геологогеоморфологического строения подводного рельефа и нижней границы обитания донной растительности. 


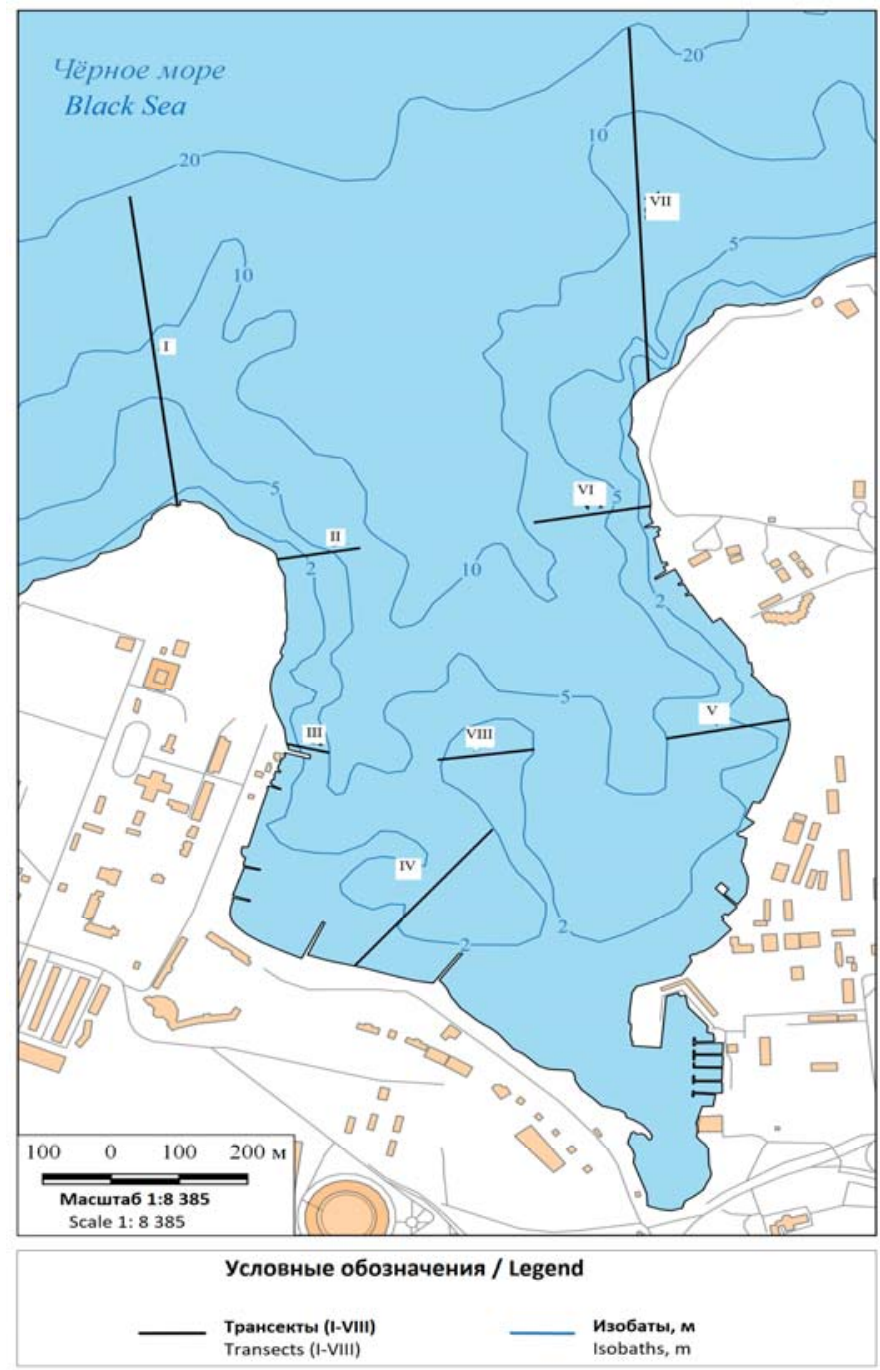

Рисунок 1. Картосхема района исследований (I-VIII - номера разрезов)

Figure 1. Schematic map of region investigated (I-VIII - section numbers)

Таблица 1. Координаты, диапазон глубин и ширина фитали на гидроботанических разрезах в бухте Круглая Table 1. Coordinates, depth range and width range of phytal on hydrobotanical transects in Kruglaya Bay

\begin{tabular}{lcrcc}
\hline \multirow{2}{*}{$\begin{array}{c}\text { No paзреза } \\
\text { Section }\end{array}$} & \multicolumn{2}{c}{$\begin{array}{c}\text { Координаты } \\
\text { Coordinates }\end{array}$} & \multicolumn{2}{c}{$\begin{array}{c}\text { Диапазон глубин, } \mathbf{M} \\
\text { Depth range, } \mathrm{m}\end{array}$} \\
\cline { 2 - 5 } & $\begin{array}{c}\text { Северная широта } \\
\text { North latitude }\end{array}$ & $\begin{array}{c}\text { Bосточная долгота } \\
\text { East longitude }\end{array}$ & $\mathbf{2 0 1 7 - 2 0 1 8}$ & $\mathbf{1 9 7 7}$ \\
\hline I & $44^{\circ} 36^{\prime} 08^{\prime \prime}$ & $33^{\circ} 26^{\prime} 13^{\prime}$ & $0,5-15$ & $0,5-20$ \\
II & $44^{\circ} 36^{\prime} 16^{\prime \prime}$ & $33^{\circ} 26^{\prime} 26^{\prime \prime}$ & $0,5-7(10)$ & $0,5-5$ \\
III & $44^{\circ} 36^{\prime} 06^{\prime \prime}$ & $33^{\circ} 26^{\prime} 27^{\prime \prime}$ & $0,5-5$ & - \\
IV & $44^{\circ} 36^{\prime} 54^{\prime \prime}$ & $33^{\circ} 26^{\prime} 31^{\prime \prime}$ & $0,5-2,5(3)$ & $0,5-5$ \\
V & $44^{\circ} 36^{\prime} 01^{\prime \prime}$ & $33^{\circ} 26^{\prime} 57^{\prime \prime}$ & $0,5-5$ & $0,5-10$ \\
VI & $44^{\circ} 36^{\prime} 22^{\prime \prime}$ & $33^{\circ} 26^{\prime} 51^{\prime \prime}$ & $0,5-7(10)$ & $0,5-20$ \\
VII & $44^{\circ} 36^{\prime} 25^{\prime \prime}$ & $33^{\circ} 27^{\prime} 02^{\prime \prime}$ & $0,5-10$ & $0,5-1$ \\
VIII & $44^{\circ} 36^{\prime} 06^{\prime \prime}$ & $33^{\circ} 26^{\prime} 41^{\prime \prime}$ & $0,5-1$ & \\
\hline
\end{tabular}

Дайвер-исследователь, снабженный дайвкомпьютером, проходил вдоль мерной линии (трансекты), отмечая глубину смены ландшафта, нижнюю границу фитали, при этом выполняя фото- и видеосъемку. В зависимости от прозрачности воды радиус исследуемой площади дна вдоль трансекты составлял примерно 10-15 м. На ключевых точках, которые располагали на стандартных глубинах $(0,5 ; 1$;
3; 5; 10; 15 и 20 м), используемых при гидроботанических исследованиях, дайвер визуально описывал донные отложения, пользуясь общепринятой классификацией морских обломочных осадков по гранулометрическому составу. Для изучения состава и структуры донных фитоценозов на этих стандартных глубинах закладывали по четыре учетные площадки размером 25×25 см, при этом учитывали проективное 
покрытие дна макрофитами. Всего заложено 34 станции, собрано и обработано 136 количественных проб по стандартной методике, применяемой в морской фитоценологии [18]. Выделение фитоценозов проводили согласно доминантной классификации по А.А. Калугиной-Гутник [18].

Информацию о донных компонентах, полученную в ходе водолазного описания, оформляли графически в виде ландшафтного профиля. В основе ландшафтного профиля лежит батиметрическая кривая, составленная в результате предварительного анализа навигационной карты и водолазного промера. На батиметрической кривой различными условными обозначениями отражали литофациальные разности донных осадков и массовые виды макрофитов. В дальнейшем выделяли однотипные участки морского дна, приуроченные к одной мезоформе рельефа, имеющие одинаковые по происхождению и составу слагающие горные породы и характерные фитоценозы. Вертикальными линиями, разделяющими профиль на серию отрезков, показывали границы ДПК. Таким образом, для бухты Круглая составлены ландшафтные профили для пятнадцати разрезов. Примеры ландшафтных профилей и схемы распределения доминирующих видов макрофитов приведены на рисунке 2.

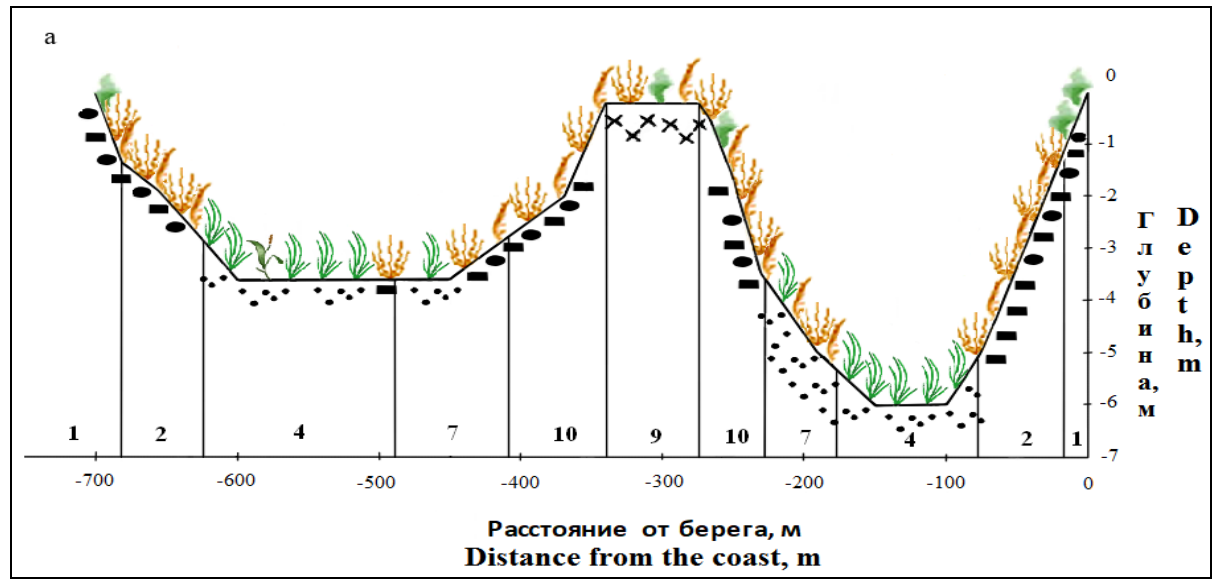

Примечание: нумерация и описание ДПК соответствует сведениям, представленным на рисунке 3 Note: the numbering and description of the BNC correspond to the information presented in Figure 3

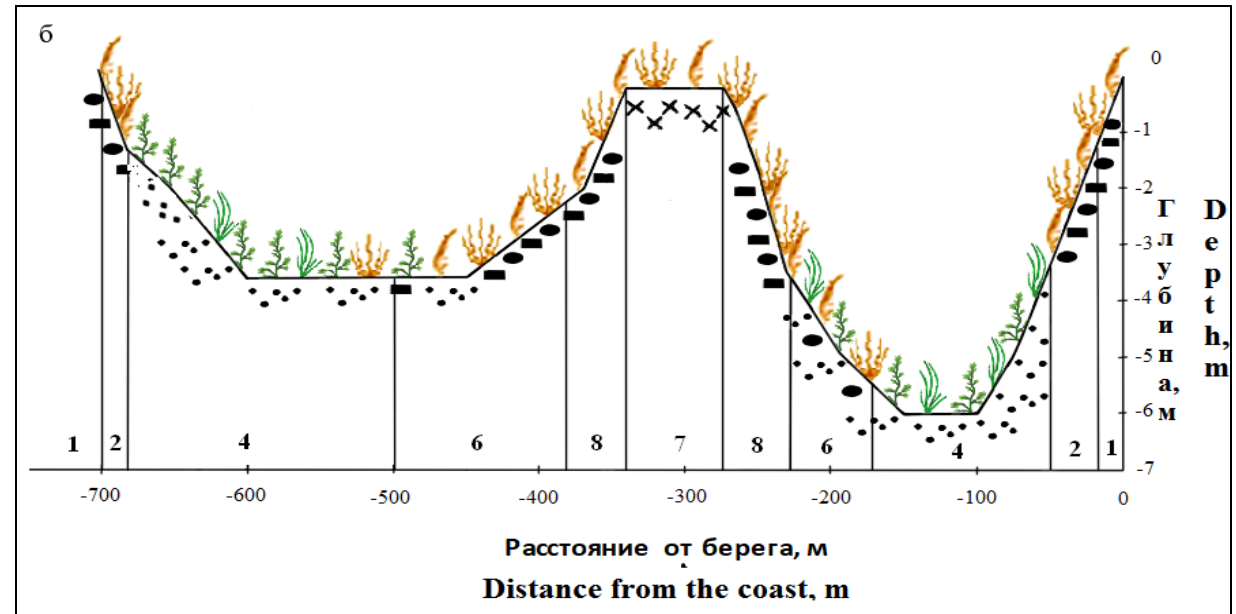

Примечание: нумерация и описание ДПК соответствует сведениям, представленным на рисунке 4 Note: the numbering and description of the BNC correspond to the information presented in Figure 4

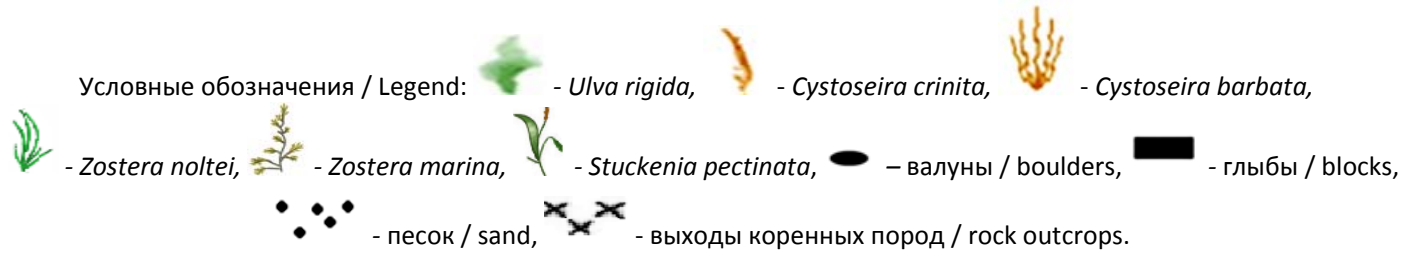

Рисунок 2. Ландшафтные профили (разрезы III, V, VIII) и схема распределения доминирующих видов макрофитов в бухте Круглая: а - 2018 г., б- 1977 г.

Примечание: I-VIII - нумерация разрезов соответствует условным обозначениям, представленным на рисунке 1

Figure 2. Landscape profiles (sections III, V, VIII) and the distribution pattern of the dominant macrophyte species in Kruglaya Bay: a - 2018, b-1977

Note: I-VIII - numbering of sections corresponds to the legend presented in Figure 1 
Для создания ландшафтной карты использовали программный пакет QGIS 2.18.17 и электронную основу навигационной карты. Географическую привязку границ ДПК осуществляли с помощью программы QGIS. Сопряженный анализ батиграфии, карт литологического состава и данных водолазной съемки позволили провести экстраполяцию участков дна со сходными параметрами для выделения границ ДПк. Результаты обобщения исследований ДПК бухты Круглая отражены на ландшафтных картах.

\section{ПОЛУЧЕННЫЕ РЕЗУЛЬТАТЫ И ИХ ОБСУЖДЕНИЕ}

В 2018 г. в ландшафтной структуре бухты Круглой выделено десять ДПК с участием доминирующих видов макрофитов: цистозиры (Cystoseira barbata C. Ag. и C. crinita (Desf.) Bory), филлофоры (Phyllophora crispa (Huds.) P.S. Dixon = Ph. nervosa (DC) Grev.), взморника Нольта (Zostera noltei Hornem) и рдеста гребенчатого (Stuckenia pectinata (L.) Börner = Potamogeton pectinatus L.). В 1977 г. в ландшафтной структуре бухты выделено восемь ДПК.

1. Глыбово-валунная отмостка и выходы коренных пород $c$ доминированием видов иистозиры. ДПК расположен вдоль восточного и западного побережья, за исключением вершины (южной) части бухты, на глубине 0,5-1 м (рис. 3). Подводная приурезовая зона представлена слабоокатанными глыбами, валунами с незначительной примесью гальки, которые подстилаются сарматскими слоистыми известняками. Размеры обломочного материала составляют 1-1,5 м, а отдельные глыбы достигают в диаметре 2-3 м. Общая площадь этого ДПК небольшая (2,2\% общей площади акватории бухты) (табл. 2). Здесь представлен фитоценоз Cystoseira crinita + C. barbata-Cladostephus spongiosus - Ellisolandia elongata [=Corallina mediterranea]. Его биомасса колеблется в широком интервале, при этом наибольшая количественная величина отмечена на внешнем западном мысе (глубина 0,5 м), а наименьшая - в средней части восточного прибрежья (глубина 1 м) (табл. 2). На изучаемых глубинах вдоль обоих прибрежий доля видов цистозиры довольно высокая (табл. 2). На внешнем восточном мысе изредка встречается Phyllophora crispa. На этом ДПК, начиная с внутреннего западного мыса, вдоль всего прибрежья до внутреннего восточного мыса бухты обнаружена Ulva rigida C. Аg., вклад которой изменяется от 0,1 до 6,9\% общей биомассы макрофитов, при этом ее максимум зарегистрирован В средней части восточного прибрежья. Доля участия эпифитной синузии в общей биомассе макрофитов значительно варьирует, при этом наибольшая величина биомассы эпифитов отмечена на том же участке и глубине, где зарегистрированы минимальные показатели биомассы макрофитов, видов цистозиры и обильно произрастает ульва (табл. 2). Среди эпифитирующих видов водорослей преобладают Vertebrata subulifera (C. Ag.) Kuntz. = Polysiphonia subulifera $(0,4-16,0 \%$ общей биомассы макрофитов) и Sphacelaria rhizoides (Roth) C. Ag. (0,9$30,9 \%$ общей биомассы макрофитов). Характерно, что наиболее существенная доля сфацилярии, составляющая примерно половину биомассы цистозиры, на которой этот вид эпифитирует, обнаружена в средней части западного прибрежья бухты.

Этот ДПК с этим же фитоценозом выделяли сорок лет назад (1977-2018 гг.). В 1977 г. его площадь была в 1,6 раза меньше в связи с тем, что гидроботаническая съемка не проводилась в южной части бухты в (рис. 4; табл. 2). Биомасса макрофитов также колебалась в широком интервале, при этом ее наибольшая количественная величина отмечена на внешнем восточном мысе (глубина 1 м), а наименьшая - в средней части западного прибрежья (глубина 0,5 м), где из-за высокой доли гравийно-песчаных отложений, скопления макрофитов незначительные (табл. 2). Вклад видов цистозиры тоже варьировал в широком диапазоне, причем максимальный показатель зарегистрирован на внешнем западном мысе на глубине 0,5 м, а минимальный - на внутреннем восточном мысе на глубине $1 \mathrm{~m}$. Phyllophora crispa единично встречалась на внешнем западном мысе. В 1977 г. на этом ДПК Ulva rigida не обнаружена. В этот период вклад эпифитов в общую биомассу макрофитов был существенно ниже, чем 40 лет спустя (табл. 2). Среди них доминировала Vertebrata subulifera (0,410,6\% общей биомассы макрофитов).

2. Подводный береговой абразионный склон, сложенный псефитовыми отложениями с выходами коренных пород с преобладанием видов цистозиры. ДПК описан вдоль западного и восточного побережья, за исключением вершины (южной) части бухты, на глубине 1-7(10) м (рис. 3). Подводный склон приглубый. В геологическом строении подводного берегового склона принимают участие породы верхнего миоцена, представленные сарматскими слоистыми известняками перекрытые чехлом четвертичных $и$ современных накоплений делювиально-пролювиального и техногенного генезиса. Общая площадь этого дпк наибольшая и составляет свыше $30 \%$ общей площади акватории бухты (табл. 2). Здесь также зарегистрирован фитоценоз Cystoseira crinita + C. barbata - Cladostephus spongiosus - Ellisolandia elongata. Его биомасса широко колеблется по глубинам и участкам. Максимальный показатель отмечен на внутреннем западном мысе на глубине 3 м, а минимальный - в этом же районе на глубине 10 м. Вклад видов цистозиры на ДПК достигает высоких значений (табл. 2). Доля филлофоры в общей биомассе макрофитов на внешних и внутренних мысах обоих прибрежий существенно возрастает с увеличением глубины. Вклад эпифитной синузии в общую биомассу макрофитов довольно значительный, причем наибольшая величина этого показателя зарегистрирована на внешнем западном мысе на глубине 5 м (табл. 2). Среди эпифитов обильно представлены Vertebrata subulifera (1,5-23,2\% общей биомассы макрофитов) и Sphacelaria rhizoides (0,431,5\% общей биомассы макрофитов).

Этот ДПК также выделяли сорок лет назад. В 1977 г. его площадь была максимальной за весь период изучения, что связано с расширением ареала цистозирового фитоценоза до глубины 15 м (рис. 4; табл. 2). В этот период биомасса водорослей также существенно изменялась по глубинам, при этом ее 
максимальная количественная величина отмечена в средней сублиторальной зоне (глубина 5 м) внешнего западного мыса, а минимальная - в нижней сублиторали (глубина 15 м) этого же мыса (табл. 2). Вклад видов цистозиры в общую биомассу макрофитов был высоким вдоль обоих прибрежий, незначительно варьировал. Доля участия Phyllophora crispa не превышала 8\% общей биомассы макрофитов. Вклад эпифитов вдоль внешних и внутренних мысов обоих прибрежий бухты был в 3-50 раз ниже, чем в 2018 г., среди эпифитов преобладали Vertebrata subulifera (1,1$11,8 \%$ общей биомассы макрофитов) и виды Laurencia (0,1-1,9\% общей биомассы макрофитов) (табл. 2).

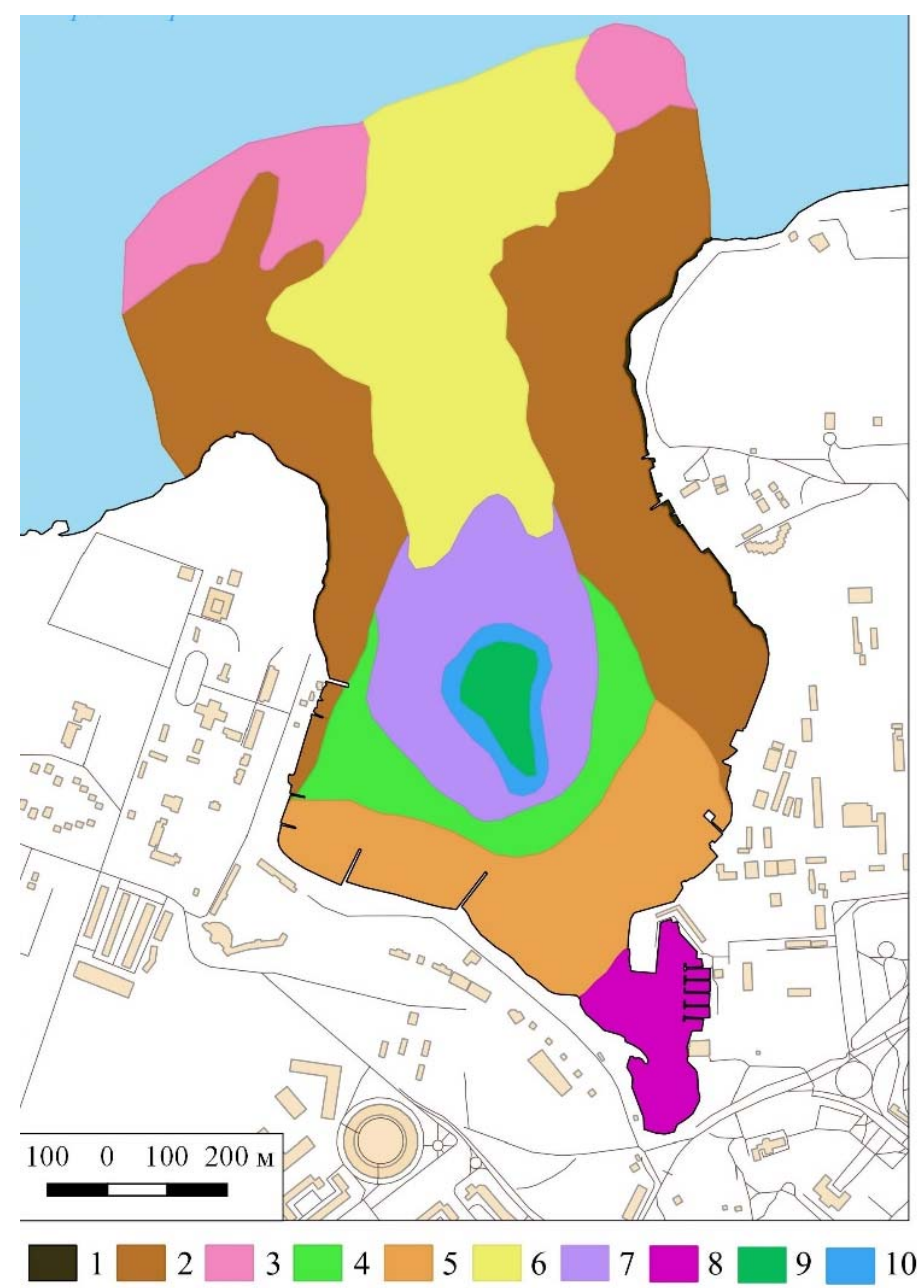

Условные обозначения: 1 - глыбово-валунная отмостка и выходы коренных пород с доминированием видов цистозиры; 2 - подводный береговой абразионный склон, сложенный псефитовыми отложениями с выходами коренных пород и с преобладанием видов цистозиры; 3 - подводный береговой абразионный склон, сложенный псефитовыми отложениями с выходами коренных пород с доминированием видов цистозиры и с чередованием гравийно-псаммитовых отложений, где преобладает филлофора курчавая; 4 - слабонаклонная аккумулятивная равнина, сложенная алеврито-псаммитовыми донными осадками, где доминирует взморник Нольта; 5 - слабонаклонная аккумулятивная равнина, сложенная псаммитовоалевритовыми отложениями с господством сообщества морских трав (взморника Нольта и рдеста гребенчатого); 6 - слабонаклонная аккумулятивная равнина, сложенная псаммитово-гравийными отложениями, лишенная донной растительности; 7-слабонаклонная аккумулятивная равнина с выходами коренных пород, где разреженно встречаются виды цистозиры, а на псаммитово-алевритовом субстрате единично произрастает взморник Нольта; 8-слабонаклонная аккумулятивная равнина, сложенная алеврито-пелитово-псаммитовыми донными осадками с деградированным сообществом макрофитов; 9-вершина подводной гряды с преобладанием видов цистозиры; 10 - подводные склоны гряды, сложенные псефитовыми отложениями с выходами коренных пород с доминированием видов цистозиры

Legend: 1 - block-boulder blind area and outcrops of bedrock with dominance of Cystoseira species; 2 - upper shoreface abrasion slope consisting of psephitic sediments and with dominance of Cystoseira species; 3 - upper shoreface abrasion slope consisting of psephitic sediments with outcrops of bedrock with dominance of Cystoseira species and with gravel-psammitic sediments with dominance of Phyllophora crispa; 4 - gently dipping accumulation plain consisting of silt-psammitic sediments with dominance of Zostera marina; 5 -gently dipping accumulation plain consisting of psammitic-silt sediments with dominance community of seagrass (Zostera noltei and Stuckenia pectinata); 6 -gently dipping accumulation plain consisting of psammitic-gravel sediments devoid of bottom vegetation; 7-gently dipping accumulation plain with outcrops of bedrock where sparsely Cystoseira species, on of silt-psammitic sediments a single grow Zostera noltei; 8 - gently dipping accumulation plain consisting silt-psammitic sediments with degraded community of macrophytes; 9 - peak underwater ridge with dominance of Cystoseira species; 10 - upper shoreface underwater ridge with outcrops of bedrock with dominance of Cystoseira species

Рисунок 3. Картосхема ландшафтной структуры дна бухты Круглая (2018 г.)

Figure 3. Schematic map of Kruglaya Bay seascape structure in 2018 
Таблица 2. Изменение площади, биомассы макрофитов, доли доминирующих видов водорослей и их эпифитов в ДПК с доминированием цистозиры и филлофоры в бухте Круглая при увеличении глубины по годам

Table 2. Change in area, biomass of macrophytes and proportion of dominant epiphytic species in BNC with the dominance of cystoseira and phyllophora of Kruglaya Bay with increasing depth by year

\begin{tabular}{|c|c|c|c|c|c|c|c|}
\hline \multirow[t]{2}{*}{$\begin{array}{l}\text { मחк } \\
\text { BNC }\end{array}$} & \multirow[t]{2}{*}{$\begin{array}{l}\text { Год } \\
\text { Year }\end{array}$} & \multirow{2}{*}{$\begin{array}{l}\text { Площадь, } \\
\text { га } \\
\text { Area }\end{array}$} & \multirow{2}{*}{$\begin{array}{c}\text { Глубина, } \\
\text { м } \\
\text { Depth, m }\end{array}$} & \multirow{2}{*}{$\begin{array}{c}\text { Биомасса макрофитов, } r \cdot \mathrm{m}^{-2} \\
\text { Biomass of macrophytes, } \\
\mathrm{gm} \cdot \mathrm{m}^{-2}\end{array}$} & \multicolumn{3}{|c|}{$\begin{array}{c}\text { Доля, \% } \\
\text { Proportion, \% }\end{array}$} \\
\hline & & & & & $\begin{array}{l}\text { Цистозиры } \\
\text { Cystoseira }\end{array}$ & $\begin{array}{l}\text { Филлофоры } \\
\text { Phyllophora }\end{array}$ & $\begin{array}{l}\text { Эпифитов } \\
\text { Epiphytic }\end{array}$ \\
\hline \multirow[t]{2}{*}{1} & 2018 & 2,2 & $0,5-1$ & $7734,8 \pm 1210,3-2906,4 \pm 370,8$ & $91,9-55,1$ & $0-0,3$ & $4,6-39,7$ \\
\hline & 1977 & 1,4 & $0,5-1$ & $981,8 \pm 292,2-6642,5 \pm 1156,7$ & $98,5-24,1$ & $0,1-0,3$ & $1,0-10,8$ \\
\hline \multirow[t]{2}{*}{2} & 2018 & 30,8 & $1-7(10)$ & $7036,0 \pm 876,2-1108,0 \pm 148,3$ & $87,6-61,4$ & $0,1-9,7$ & $10,3-38,4$ \\
\hline & 1977 & 40,6 & $1-15$ & $4857,0 \pm 690,0-471,4 \pm 112,5$ & $98,9-75,7$ & $0,2-7,4$ & $14,4-0,2$ \\
\hline \multirow[t]{2}{*}{3} & 2018 & 10,0 & $10-15$ & $651,5 \pm 138,9-900,4 \pm 125,7$ & $25,1-0$ & $52,6-88,1$ & $21,9-11,8$ \\
\hline & 1977 & 5,8 & $15-20$ & $63,2 \pm 15,4-314,3 \pm 104,8$ & 0 & $98,1-100$ & 0 \\
\hline \multirow[t]{2}{*}{ 9-10 } & 2018 & 1,5 & $0,5-1$ & $4964,4 \pm 534,8-4991,6 \pm 624,7$ & $86,4-85,0$ & $0,2-0$ & $11,6-12,7$ \\
\hline & 1977 & 1,5 & $0,5-1$ & $5060,3 \pm 723,7-3722,4 \pm 547,4$ & $85,2-89,5$ & 0 & $14,8-10,5$ \\
\hline
\end{tabular}

Примечание: нумерация и описание ДПК соответствует сведениям, представленным на рисунке 3, 4

Note: the numbering and description of the BNC correspond to the information presented in Figure 3,4

3. Подводный береговой абразионный склон, сложенный псефитовыми отложениями с выходами коренных пород с доминированием видов цистозиры и с чередованием гравийно-псаммитовых отложений, где преобладает филлофора курчавая. ДПК зарегистрирован в районе внешних мысов западного и восточного побережья на глубине от 10 до 15 м (рис. 3). Для рельефа дна характерны выходы сарматских известняков в виде плит с гребнями, здесь представлен фитоценоз Cystoseira crinita + C. barbata-Cladostephus spongiosus - Ellisolandia elongata. Межгрядовые понижения заполнены мелкообломочным материалом с включением детритуса ракуши, где зафиксирован фитоценоз Phyllophora crispa. Общая площадь ДПк составляет почти $10 \%$ общей площади акватории бухты (табл. 2). Биомасса макрофитобентоса колеблется в узком диапазоне, при этом ее наибольшая величина отмечена на западном мысе на глубине $15 \mathrm{~m}$, а наименьшая - на восточном мысе на глубине $10 \mathrm{~m}$ (табл. 2). Доля видов цистозиры значительно ниже по сравнению с этим же показателем у филлофоры. Характерно, что в эпифитную синузию основной вклад вносит сезонно-зимний вид Ectocarpus sp. (11,8-19,3\% общей биомассы макрофитов).

В 1977 г. этот ДПК был отмечен в этом же районе, но на большей глубине (рис. 4; табл. 2). Его площадь в 1,7 раза ниже, чем в 2018 г. Биомасса макрофитов невысокая, при этом господствовала Phyllophora crispa, тогда как Cystoseira spp. встречались единично. Эпифиты на этих глубинах отсутствовали.

4. Слабонаклонная аккумулятивная равнина, сложенная псаммитово-алевритовыми отложениями, где доминирует взморник Нольта. ДПк занимает южную часть бухты на глубине 3-5 м. Для него характерна равнина, имеющая уклон к скалистой отмели, расположенной в центральной части бухты. Наклонная поверхность, в основном, сложена фракциями мелко- и среднезернистого песка. Его площадь не превышает 5\% общей площади бухты (рис. 3; табл. 3). Здесь зарегистрирован фитоценоз морской травы - Zostera noltei. Биомасса макрофитов при увеличении глубины возрастает вчетверо, при этом доминирует эдификатор фитоценоза (табл. 3). Доля участия Stuckenia pectinata в южной части бухты на глубине 3 м не превышает 6\%, тогда как глубже встречается единично. Эпифитная синузия развита слабо (табл. 3).

Сорок лет назад на этом участке был описан ДПК с доминированием видов взморника (морского и Нольта). В 1977 г. его площадь была вчетверо ниже в связи с тем, что гидроботаническая съемка не проводилась в южной части бухты (рис. 4; табл. 3). Здесь был представлен фитоценоз Zostera marina+ Z. noltei. Биомасса высшей водной растительности была вдвое выше, чем в настоящее время. Вклад Zostera marina L. существенно преобладал над этим же показателем Z. noltei. В тот период Stuckenia pectinata не зафиксирована. Доля эпифитов также незначительна (табл. 3).

5. Слабонаклонная аккумулятивная равнина, сложенная псаммитово-алевритовыми отложениями с господством сообщества морских трав (взморника Нольта и рдеста гребенчатого). ДПК отмечен в южной части бухты на глубине 0,5-3 м. Рельеф представляет выровненную поверхность с песчаноилистыми донными осадками. В приурезовой зоне наблюдается дефицит песка, преобладают валуны и крупная галька. Площадь ДПК составляет около $13 \%$ общей площади бухты (рис. 3; табл. 3). Здесь зарегистрирован фитоценоз Zostera noltei + Stuckenia pectinata. В структуре фитоценоза, помимо доминанта и содоминанта, отмечены виды Ruppia, единично встречается Zostera marina. Биомасса морских трав варьирует в узком интервале. Доля взморника Нольта вдвое выше, чем рдеста гребенчатого (табл. 3). Среди эпифитов преобладает Laurencia obtusa (1,4-3,5\% общей биомассы макрофитов). В 1977 г. гидроботаническую съемку в этой части бухты не проводили. 
6. Слабонаклонная аккумулятивная равнина, сложенная псаммитово-гравийными отложениями, лишенная донной растительности. ДПК занимает северную центральную часть бухты на глубине 7(10)-15 м (рис. 3). Рельеф представляет выровненную поверхность, сложенную песчано-гравийными донными осадками. Его площадь достигает около $20 \%$ общей площади бухты. Этот ДПК также регистрировали сорок лет назад (рис. 4).

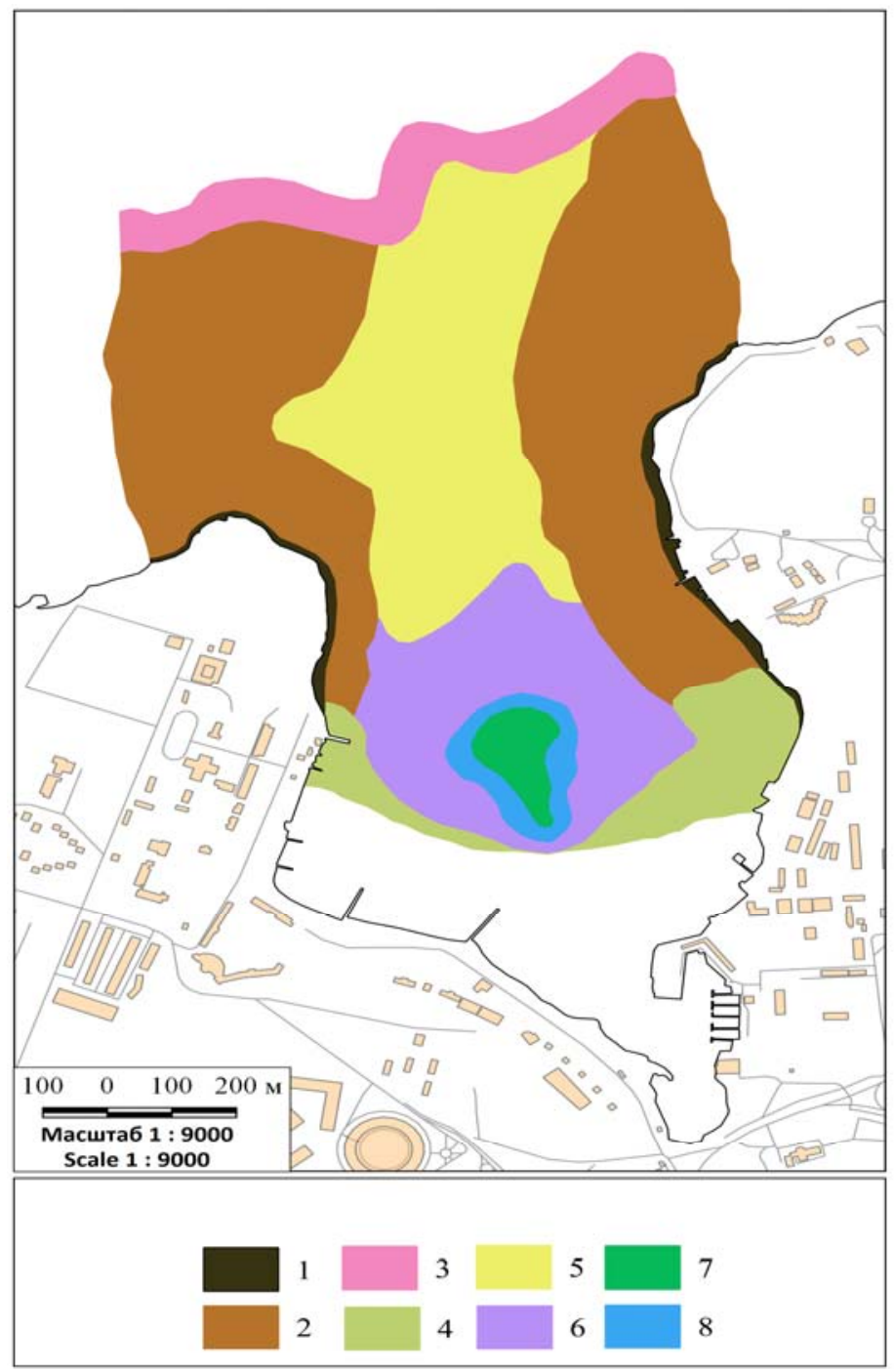

Условные обозначения: 1 - глыбово-валунная отмостка и выходы коренных пород с доминированием видов цистозиры; 2 - подводный береговой абразионный склон, сложенный псефитовыми отложениями с выходами коренных пород и с преобладанием видов цистозиры; 3 - подводный береговой абразионный склон, сложенный псефитовыми отложениями с выходами коренных пород с доминированием видов цистозиры и с чередованием гравийно-псаммитовых отложений, где преобладает филлофора курчавая; 4 - слабонаклонная аккумулятивная равнина, сложенная алеврито-псаммитовыми донными осадками, с доминированием видов взморника (морского и Нольта); 5 -слабонаклонная аккумулятивная равнина, сложенная псаммитово-гравийными отложениями, лишенная донной растительности; 6 - слабонаклонная аккумулятивная равнина с выходами коренных пород, где разреженно встречаются виды цистозиры, а на псаммитово-алевритовом субстрате единично произрастают виды взморника; 7-вершина подводной гряды с преобладанием видов иистозиры; 8 - подводные склоны гряды, сложенные псефитовыми отложениями с выходами коренных пород с доминированием видов цистозиры Legend: 1 - block-boulder blind area and outcrops of bedrock with dominance of Cystoseira species; 2 - upper shoreface abrasion slope consisting of psephitic sediments with outcrops of bedrock with dominance of Cystoseira species; 3 - upper shoreface abrasion slope consisting of psephitic sediments with outcrops of bedrock with dominance of Cystoseira species and with gravel-psammitic sediments with dominance of Phyllophora crispa; 4 -gently dipping accumulation plain consisting of silt-psammitic sediments with dominance of Zostera species; 5 - gently dipping accumulation plain consisting of psammitic-gravel sediments devoid of bottom vegetation; 6 - gently dipping accumulation plain with outcrops of bedrock where sparsely Cystoseira species, on of silt-psammitic sediments a single grow Zostera species; 7-peak underwater ridge with dominance of Cystoseira species; 8-upper shoreface underwater ridge with outcrops of bedrock with dominance of Cystoseira species

Рисунок 4. Картосхема ландшафтной структуры дна бухты Круглая (1977 г.)

Figure 4. Schematic map of Kruglaya Bay seascape structure in 1977 
Таблица 3. Изменение площади, биомассы макрофитов, доли доминирующих видов и их эпифитов в ДПк с доминированием морских трав в бухте Круглая при увеличении глубины по годам

Table 3. Change in area, biomass of macrophytes, proportion of dominant and epiphytic species in BNC with the dominance of marine grasses of Kruglaya Bay with increasing depth over the years

\begin{tabular}{|c|c|c|c|c|c|c|c|}
\hline \multirow[t]{2}{*}{$\begin{array}{l}\text { ДПк } \\
\text { BNC }\end{array}$} & \multirow[t]{2}{*}{$\begin{array}{l}\text { Год } \\
\text { Year }\end{array}$} & \multirow{2}{*}{$\begin{array}{c}\text { Площадь, } \\
\text { га } \\
\text { Area, ha }\end{array}$} & \multirow{2}{*}{$\begin{array}{c}\text { Биомасса макрофитов, } \mathbf{r} \cdot \mathbf{m}^{-2} \\
\text { Biomass of macrophytes, } \\
\mathrm{gm} \cdot \mathrm{m}^{2}\end{array}$} & \multicolumn{4}{|c|}{$\begin{array}{c}\text { Доля, \% } \\
\text { proportion \% }\end{array}$} \\
\hline & & & & $\begin{array}{c}\text { Взморника } \\
\text { Нольта } \\
\text { Zostera } \\
\text { noltei }\end{array}$ & $\begin{array}{c}\text { Рдеста } \\
\text { гребенчатого } \\
\text { Stuckenia } \\
\text { pectinata }\end{array}$ & $\begin{array}{c}\text { Взморника } \\
\text { морского } \\
\text { Zostera marina }\end{array}$ & $\begin{array}{r}\text { Эпифитов } \\
\text { Epiphytic }\end{array}$ \\
\hline \multirow[t]{2}{*}{4} & 2018 & 4,7 & $287,3 \pm 63,4-1111,0 \pm 150,3$ & $91,5-99,9$ & $5,3-0$ & 0 & $2,3-0,1$ \\
\hline & 1977 & 1,3 & $490,8 \pm 184,9-2569,5 \pm 809,8$ & $2,9-38,4$ & 0 & $97,1-58,6$ & $0-2,5$ \\
\hline 5 & 2018 & 12,8 & $1253,4 \pm 167,3-1097,0 \pm 381,5$ & $64,4-56,8$ & $30,8-37,2$ & 0 & $1,4-3,6$ \\
\hline
\end{tabular}

Примечание: нумерация и описание ДПК соответствует сведениям, представленным на рисунке 3, 4

Note: the numbering and description of the BNC correspond to the information presented in Figure 3, 4

7. Слабонаклонная аккумулятивная равнина с
выходами коренных пород, где разреженно встречаются виды цистозиры, а на псаммитовоалевритовом субстрате единично произрастает взморник Нольта. ДПК расположен в центральной части бухты на глубине 3-6 м (рис. 3). Для рельефа характерны слабоокатанные глыбы известняков (размер 0,5-1,0 м) в виде плитообразных обломков. Его площадь превышает $13 \%$ общей площади бухты. Донная растительность представлена мозаично. Этот ДПК отмечали и в 1977 г. (рис. 4).

8. Слабонаклонная аккумулятивная равнина, сложенная алеврито-пелитово-псаммитовыми отложениями с деградированным сообществом макрофитов. ДПК занимает устьевую, кутовую часть бухты, представляет выровненную поверхность, сложенную илисто-песчаными донными осадками. Его глубина не превышает 1-2 м. Площадь ДПК составляет около 6\% общей площади бухты (рис. 3). Здесь разреженно единично встречаются угнетенные или обрывки зеленых видов водорослей и морских трав. В 1977 г. гидроботаническую съемку в этой части бухты не проводили.

9. Вершина подводной гряды с преобладанием видов цистозиры. ДПК занимает центральную часть бухты и представляет скалистую отмель с глубиной 0,5-0,6 м. Площадь ДПк незначительная (0,8\% общей площади бухты) (рис. 3; табл. 2). Здесь зарегистрирован фитоценоз Cystoseira crinita + C. barbata - Cladostephus spongiosus - Ellisolandia elongata. Биомасса макрофитов и вклад видов цистозиры высокие. В составе фитоценоза отмечена Ulva rigida, доля ее участия составляет 1,5\% общей биомассы макрофитов. Среди эпифитов преобладает Sphacelaria rhizoides (9,9\% общей биомассы макрофитов).

Этот ДПК выделяли в 1977 г. (рис. 4). Величина биомассы макрофитов, вклад видов цистозиры оказались соизмеримыми и практически не изменились за прошедшие сорок лет (табл. 2). В тот период в структуре фитоценоза Ulva rigida не зафиксирована. В эпифитной синузии доминировала Vertebrata subulifera $(13,4 \%$ общей биомассы макрофитов).
10. Подводные склоны гряды, сложенные псефитовыми отложениями с выходами коренных пород с доминированием видов цистозиры. ДПК расположен вокруг подводной гряды в центральной части бухты на глубине 1 м. Рельеф характеризуется очень крутыми склонами, достигающими глубины 5 м. Площадь ДПК минимальная $(0,7 \%$ общей площади бухты) (рис. 3; табл. 2). Зафиксирован фитоценоз Cystoseira crinita + C. barbata - Cladostephus spongiosus Ellisolandia elongata. Биомасса макрофитов, вклад в ее структуру видов цистозиры достаточно высокие, сравнимые с показателями на предыдущем ДПк. В составе фитоценоза также отмечена Ulva rigida, доля ее участия не превышает $0,7 \%$ общей биомассы макрофитов. Среди эпифитов преобладает Sphacelaria rhizoides (10,0\% общей биомассы макрофитов).

Этот ДПК регистрировали сорок лет назад (рис. 4). Величина биомассы макрофитов была в 1,3 раза ниже, чем этот показатель в 2018 г., тогда как вклад видов цистозиры был несколько выше (табл. 2). В тот период Ulva rigida в структуре фитоценоза не зафиксирована. В 1977 г. в составе эпифитной синузии доминировала Vertebrata subulifera $(7,7 \%$ общей биомассы макрофитов).

В монографической сводке А.А. КалугинойГутник [18] показано, что открытые берега крымского шельфа характеризуются доминированием поясного типа донной растительности. На глыбово-валунном субстрате и выходах коренных пород на глубине от 0,5 до 10 м распространены цистозировые фитоценозы, являющиеся ключевыми звеньями большинства прибрежных экосистем. Затем следует переходная полоса, где между валунами и глыбами встречаются участки с песчаными отложениями, на глубине 10-18 м встречается цистозирово-филлофоровый фитоценоз. Следующий пояс представлен филлофоровым фитоценозом, который описан на гравийно-песчаных с битой ракушей донных осадках на глубине 18-25 м. Основу растительного покрова заливов и бухт крымского прибрежья, для которых характерны песчано-илистые и илисто-песчаные отложения, образуют фитоценозы высших цветковых растений, при этом на твердых включениях произрастают водоросли [18]. Однако, геолого-геоморфологическое строение дна нарушает поясное распределение макрофитобентоса. Кроме этого, многолетнее изучение 
донной растительности у берегов Крыма, в том числе и в бухте Круглая, за последние полвека выявили существенные структурные перестройки фитоценозов, их трансформацию, а также вертикальное изменение глубин обитания отдельных видов $[7 ; 8 ; 19]$.

Так, в работе А.А. Калугиной-Гутник с соавторами [7] отмечены значительные изменения в видовом разнообразии и количественных показателях макрофитов за более чем четверть века. В результате сравнительного анализа показано, что донная растительность в 1964 г. имела сходство с макрофитобентосом, встречающимся у открытых и чистых берегов Черного моря, тогда как в 1990 г. зарегистрирован более разнообразный видовой состав водорослей, что характерно для прибрежных районов со средней степенью загрязнения хозяйственнобытовыми стоками. И.К. Евстигнеева и Н.В. Николенко [8] на основании изучения видового состава, структуры и биомассы фитоценозов также косвенно подтвердили относительную чистоту прибрежных вод бухты Круглая в конце 70-х гг. прошлого века. В работе показано, что за период с 1987 по 1997 гг. эвтрофирование воды в бухте заметно возросло в связи с увеличением антропогенной нагрузки [7]. Авторы отмечали, что в 1987 г. средняя биомасса цистозирового фитоценоза на западном прибрежье бухты примерно в 1,3 раза ниже, чем на противоположном, что связано с отличиями в экологических условиях среды обитания и степени антропогенного воздействия. Спустя 10 лет эта тенденция сохранилась, хотя В количественном отношении уже менее выраженная. Согласно гидроботанической съемки, проведенной в 2018 г., биомасса цистозирового фитоценоза на внутренних мысах западного и восточного прибрежья бухты колебалась в пределах 7036,0-2368,3 и 6483,8-2504,4 $\Gamma \cdot \mathrm{M}^{-2}$ соответственно. Таким образом, в настоящее время варьирование биомассы фитоценозов у обоих берегов, в целом, оказалось сходным, что связано с увеличением хозяйственной нагрузки на восточный берег.

Первые картографические сведения об особенностях распределения основных видов макрофитов в бухте Круглая приведены на «Карте распределения биоценозов в Черном море у Севастополя», составленной коллективом ученых и рыбаков во главе с С.А. Зерновым [6] в 1910-1911 гг. На карте показано, что в бухте основными биотопами являются биоценоз скал, плит и биоценоз песчаноилистых с битой ракушей донных отложений. В районе входных мысов, вдоль обоих прибрежий, в центре на отмели, а также фрагментарно в южной части бухты обильно встречаются виды цистозиры. В южной и средней части бухты на рыхлом субстрате зарегистрированы заросли морских трав. В центральной северной части бухты на гальке и песке донная растительность отсутствовала. Кутовая часть бухты в то время была представлена соленым озером. Сравнительный анализ картографической информации и современных материалов гидроботанической съемки выявил, что в бухте сохранились те же доминирующие виды макрофитов и, в целом, за более чем 100 лет распределение донной растительности оказалось сходным, лишь изменились площади ареалов господствующих видов макрофитов.

Проанализировав

пространственное распределение количественных показателей макрофитобентоса на основе ландшафтного подхода в бухте Круглая за период с 1977 по 2018 г., выявлено, что в составе донной растительности произошли отрицательные изменения. Анализ направленности многолетних изменений фитобентоса показал подъем нижней границы произрастания многих глубоководных видов, сужение границ фитали, отрицательная трансформация состава и структуры фитоценозов, снижение биомассы ключевых видов макрофитов.

Сравнение биомассы макрофитов ДПК глыбововалунной отмостки с выходами коренных пород и доминированием видов цистозиры показал, что в 2018 г. их наибольшая и наименьшая величина примерно в 1,2 раза выше, чем эти показатели в 1977 г. (табл. 2). Тем не менее, за этот период максимальный вклад цистозиры уменьшился, при этом значительно возросла доля эпифитирующих видов водорослей. Минимальная биомасса цистозирового фитоценоза, зарегистрированная в 1977 г., отмечена в средней части западного прибрежья на глубине 0,5 м. В тот период на этом участке, начиная с глубины 1 м, обильно встречалась Zostera marina, приуроченная к песчаноилистым донным отложениям, а на глубине 0,5 м отмечена высокая доля песчано-гравийных прогалин (рис. 26). В 2018 г. в этом районе морские травы стали произрастать только с глубины 3 м, что свидетельствует о смещении рыхлых наносов и обнажении коренных пород (рис. 2а). Аналогичный процесс произошел и в средней части восточного прибрежья. В 1977 г. Zostera marina зарегистрирована на глубине 3 м, тогда как в 2018 г. - высшая водная растительность отмечена начиная с глубины 5 м (рис. 2).

Известно, что с повышением загрязнения прибрежных вод структура донных фитоценозов усложняется, биомасса видов цистозиры снижается, а эпифитирующих на них водорослей - увеличивается [18]. В пользу этого утверждения свидетельствует массовое появление Ulva rigida в составе фитоценозов этого ДПК, при этом ее максимум зарегистрирован в средней части восточного прибрежья на глубине $1 \mathrm{~m}$, где отмечена наибольшая величина биомассы эпифитов и наименьшая - видов цистозиры, что, вероятно, связано с активным освоением береговой зоны (табл. 2).

Сходные изменения выявлены в составе донной растительности ДПК вершины подводной гряды, где преобладают виды цистозиры и ДПК подводного склона гряды, сложенного псефитовыми отложениями с выходами коренных пород с доминированием видов цистозиры. Здесь в структуре цистозировых фитоценозов также появилась ульва, которая не зарегистрирована в 1977 г.

За период исследования (1977-2018 гг.) отмечены изменения не только в границах контура ДПк подводного берегового абразионного склона, сложенного псефитовыми отложениями с выходами коренных пород и с преобладанием видов цистозиры, но и в качественных и количественных показателях макрофитобентоса. Так, максимальная биомасса 
цистозирового фитоценоза в 2018 г. примерно в полтора раза превышает эту величину, зарегистрированную в 1977 г. (табл. 2). Увеличение плотности зарослей цистозиры в верхней сублиторальной зоне на глубине от 0,5 до 3 м свидетельствует о смещении ее экологофитоценотического оптимума, который ранее был приурочен к глубине 3-5 м [18]. В конце прошлого столетия подобные изменения описаны для цистозировых фитоценозов прибрежий Крыма и Кавказа $[19 ; 20]$.

В 1977 г. площадь этого ДПК в 1,3 раза больше, чем сорок лет спустя, что связано с расширением ареала цистозирового фитоценоза до глубины 15 м (табл. 2). На этой глубине биомасса фитоценоза была низкой, хотя вклад видов цистозиры достигал 90,1\% общей биомассы макрофитов. В тоже время за сравниваемый период биомасса цистозировых фитоценозов на глубине 10 м оказалась соизмеримой и составляла $1086,6 \pm 127,3$ (1977 г.) и 1108,0 $\pm 148,3$ (2018 г.) соответственно.

В настоящее время цистозировые фитоценозы характеризуются декумбацией ярусов, снижением роли видов 1 и 2-го ярусов и обильным развитием эпифитных синузий [19; 20]. Так, если в 1977 г. вклад эдификатора 2-го яруса Cladostephus spongiosus варьировал от 0,3 до 71,8\%, то к 2018 г. доля этого вида не превышала $3 \%$ общей биомассы. Существенное возрастание роли эпифитов, вероятно, является откликом цистозирового фитоценоза на повышение уровня трофности вод из-за возросшей антропогенной нагрузки, поскольку эти водоросли имеют более высокую скорость роста и большую удельную поверхность слоевищ, которая способна поглощать биогены, по сравнению с видами цистозиры и филлофоры [21].

За исследуемый период ДпК подводного берегового абразионного склона, сложенного псефитовыми отложениями с выходами коренных пород с доминированием видов цистозиры и с чередованием гравийно-псаммитовых отложений, где преобладает филлофора курчавая, также изменил границы контура. В 1977 г. этот ДПК регистрировали на глубине 15-20 м, то через 40 лет - на глубине 10-15 м, а глубже в настоящее время донная растительность отсутствует. Увеличение биомассы макрофитобентоса на мелководье и его деградация в глубоководной зоне в условиях возрастающего эвтрофирования водных масс характерна для многих участков крымского прибрежья [19]. В современных условиях отмечено смещение нижней границы произрастания филлофоры ближе к берегу, тогда как еще в 1977 г. она образовывала массовые скопления на глубине 15-20 м (табл. 2). Этот вид стал играть заметную роль в структуре цистозировых фитоценозов, в которых ранее встречался лишь единично [19].

Наиболее существенные изменения произошли на ДПК слабонаклонной аккумулятивной равнине, сложенной псаммитово-алевритовыми отложениями, где доминирует взморник Нольта. В структуре макрофитобентоса исследуемой части бухты произошла замена зостерового фитоценоза, доминантом которого являлась Zostera marina, a содоминантом - Z. noltei, на зостерово-рдестовый фитоценоз, где преобладают Z. noltei и Stuckenia pectinata. Исчезновение Z. marina и появление $S$. pectinata свидетельствует об увеличении степени заиления донных осадков [22]. Следует отметить, что в настоящее время, степень заиления дна снижается по мере удаления от берега. Так, в центральной части бухты на глубине 1-5 м сосредоточены практически «чистые» заросли взморника Нольта, тогда как рдест гребенчатый встречается лишь изредка, при этом ближе к берегу его доля существенно возрастает (табл. 3). Согласно А.А. Калугиной-Гутник [18], Z. noltei не произрастает в кутовой части бухт, где имеется подток пресных вод. Увеличение степени заиления южной мелководной части бухты Круглая согласуется со сведениями С.В. Алемова с соавторами [17], которые отмечают, что в вершинную (кутовую) часть акватории выведены стоки (аварийной канализации и ливневых вод), вызывающие распреснение и повышение количества взвешенных частиц, растворенной органики, содержания нефтепродуктов.

Аналогичное повышение численности и биомассы Z. noltei и Ruppia spp. и снижение этих показателей у Z. marina ранее отмечено в бухте Казачья, входящей в систему Севастопольских бухт, что косвенно свидетельствовало о повышении уровня нарушенности экотопа, поскольку произошла замена вида с конкурентной стратегией на виды-рудералы [22].

Таким образом, сравнительный анализ состава и биомассы фитоценозов бухты Круглая позволил установить особенности трансформации сообществ макрофитобентоса в условиях возрастающего эвтрофирования. Изучение донной растительности и ключевых видов макрофитов с учетом ландшафтной структуры дна показали отрицательные изменения в составе и структуре макрофитобентоса за период с 1977 по 2018 г., при этом особенно выраженная негативная трансформация его зафиксирована в нижней сублиторальной зоне на глубине 15-20 м.

К отрицательным антропогенным факторам, вызывающим перестройку растительной компоненты ДПК, большинство исследователей относят эвтрофикацию и снижение прозрачности воды [19; 20]. Ряд авторов добавляют природные факторы, такие как изменение климата, приводящее к изменениям температуры воды и режима ее циркуляции, усилению волновой активности и колебаний уровня моря [23].

В тоже время, по данным С.В. Алемова с соавторами [17] бухта Круглая является наименее загрязненной нефтяными углеводородами из бухт Севастопольского взморья. Авторы утверждают, что к концу века и в настоящее время, несмотря на возросшую рекреационную нагрузку, донные биоценозы бухты, в основном, не изменились, в них преобладают виды, характерные для «чистых» прибрежных биотопов. В работе показано, что по видовому разнообразию и показателям обилия донной фауны бухта Круглая превосходит все портовые акватории Севастополя и соответствует незагрязненным участкам прибрежья.

В целом, мы согласны с мнением этих авторов. В пользу этого утверждения свидетельствуют сохранность цистозировых фитоценозов и 
относительно высокие показатели биомассы макрофитов, доли видов цистозиры (табл. 2). Это также согласуется с высказанным ранее предположением о восстановлении структуры и увеличении количественных характеристик цистозиры в прибрежной мелководной зоне в условиях слабого загрязнения и умеренной рекреационной нагрузки [19]

\section{ЗАКЛЮЧЕНИЕ}

За период исследований (1977-2018 гг.) в ландшафтной структуре бухты Круглая выделены дпк с участием доминирующих видов макрофитов (Cystoseira crinita, C. barbata, Phyllophora crispa, Zostera noltei). Показано, что для глыбово-валунной отмостки, подводного абразионного склона, гряды, сложенных псефитовыми отложениями с выходами коренных пород, характерно доминирование видов цистозиры, доля которых снизилась с 76-99 (1977 г.) до 55-92\% (2018 г.) общей биомассы макрофитов. За прошедшее время структура цистозирового фитоценоза значительно усложнилась. В его составе зарегистрированы зеленые виды водорослей (Ulva rigida), возросла роль эпифитных синузий, что свидетельствует о повышении степени эвтрофирования изучаемой акватории. Площадь этих ДПК снизилась в 1,3 раза общей площади бухты. Это связано с тем, что в 1977 г. цистозировый фитоценоз простирался до глубины 15 м, тогда как в 2018 г. их граница проходит на глубине $10 \mathrm{~m}$.

В течение всего периода изучения в центральной и южной части бухты преобладали морские травы, их вклад составлял 96-99\% общей биомассы макрофитов. На этих участках акватории на слабонаклонной аккумулятивной равнине, сложенной псаммитово-алевритовыми отложениями выявлены наиболее существенные изменения ДПК. В структуре макрофитобентоса исследуемой части бухты произошла замена зостерового фитоценоза, доминантом которого являлась Zostera marina, а содоминантом - Z. noltei, на зостерово-рдестовый фитоценоз, где преобладают Z. noltei и Stuckenia pectinata. Исчезновение Z. marina и появление $S$. pectinata свидетельствует об увеличении степени заиления донных осадков. Площадь этих дПк не превышает четверти общей площади акватории.

Проанализировав пространственное распределение макрофитобентоса в бухте на основе ландшафтного подхода за более чем 40 лет, выявлено, что перестройка в структуре фитоценозов и изменение биомассы ключевых видов макрофитов, вероятно, связаны как с увеличением антропогенной нагрузки на акваторию, так и влиянием природных факторов. Комплексное воздействие этих факторов, приводит к деградации донной растительности, которая наиболее выражена в нижней сублиторальной зоне.

Применение ландшафтного подхода к изучению растительной компоненты ДПК позволило выявить закономерности пространственно-временного распространения макрофитобентоса в бухте Круглая.

Использование ландшафтных карт прибрежья может служить информационной основой для выработки принципов и принятия решений по рациональному природопользованию, а также применяться при создании различных прикладных, оценочных, инвентаризационных, конструктивных и прогнозных карт, которые являются важным звеном для разработки проектов хозяйственного освоения береговой зоны Черного моря.

\section{БЛАГОДАРНОСТИ}

Работа выполнена в рамках госзадания ФИЦ ИнБЮМ № AAAA-A18-118021350003-6. Морская экспедиция и сбор материала макрофитобентоса проведены в 2018 г по теме ФИЦ ИнБЮМ: АААА-А18-118020890074-2. Выражаем благодарность сотрудникам лаборатории фиторесурсов за совместную обработку первичного материала; Шапкину Д. за проведение глубоководной фото и видеосъемки донных природных комплексов.

\section{ACKNOWLEDGEMENTS}

This work was carried out within the framework of government procurement through Kovalevskii Institute for Marine Biological Research project no AAAA-A-

18118021350003-6. Marine expedition and collection of macrophytobenthos material carried out in 2018 through Kovalevskii Institute for Marine Biological Research project no AAAA-A18-118020890074-2.

The authors are grateful to the staff of the Laboratory of Phytoresources for the joint processing of the primary material and to D. Shapkin for conducting deep-sea photo and video shooting of bottom natural complexes.

\section{БИБЛИОГРАФИЧЕСКИЙ СПИСОК}

1. Красная книга Республики Крым. Растения, водоросли и грибы. Симферополь: ООО «ИТ «АРИАЛ», $2015.480 \mathrm{c}$.

2. Dumont H. J. (Ed.). Black Sea Red Data Book. NY: United Nations Office for Project Services, 1999. 413 p.

3. Красная книга Российской Федерации (растения и грибы). М.: Товарищество научных изданий КМК, 2008. $885 \mathrm{c}$.

4. Красная книга Севастополя. Калининград: «Издательский Дом «РОСТ-ДОАФК», 2018. 432 с. 5. Council Directive 92/43/EEC of 21 May 1992 on the conservation of natural habitats and of wild fauna and flora. URL:

http://eurlex.europa.eu/LexUriServ/LexUriServ.do?uri=CEL EX:31992L0043:EN:html (дата обращения: 19.04.2019) 6. Зернов С.А. К вопросу об изучении жизни Черного моря // Записки Императорской Академии Наук. СПб., Тип. Имп. АН., 1913. Т. 32. N 1. 304 с.

7. Калугина-Гутник А.А., Евстигнеева И.К., Миронова Н.В. Изменения донной растительности на открытом побережье Севастопольской бухты за период с 1964 по 1990 гг. // Альгология. 1993. Т. 3. N 2. С. 42-48.

8. Евстигнеева И.К., Николенко Н.В. Растительность прибрежного мелководья Черного моря в условиях антропогенного воздействия // Альгология. 2003. Т. 13. N 4. C. $371-380$.

9. Ковардаков С.А., Празукин А.В. Структурнофункциональные характеристики донного фитоценоза бухты Круглой (Севастополь) // Экосистемы, их оптимизация и охрана. 2012. N 7. С. 138-148.

10. Гурьянова Е.Ф. Теоретические основы составления карт подводных ландшафтов // Вопросы биостратиграфии континентальных толщ. М., 1959. С. 35-48. 
11. Линдберг Г.У. Картирование подводных ландшафтов с целью изучения закономерностей распределения животных // Труды III сессии Всесоюзного Палеонтологического общества «Вопросы биостратиграфии континентальных толщ». М.: Госгеолтехиздат, 1959. С. 49-52.

12. Петров К.М. Подводные ландшафты: теория, методы исследования. Л.: Наука, 1989. 126 с. 13. Миронова Н.В., Панкеева Т.В. Пространственное распределение макрофитобентоса с учетом ландшафтной структуры юго-западной части региона Севастополя // Экосистемы. 2018. N 14 (44). С. 20-30. 14. Миронова Н.В., Панкеева Т.В. Долговременные изменения пространственного распределения запасов макрофитов в бухте Ласпи (Черное море) // Экосистемы. 2018. N 16 (46). С. 33-46.

15. Pankeeva T.V., Mironova N.V. Spatiotemporal changes in the macrophytobenthos of Laspi Bay (Crimea, Black Sea) // Oceanology. 2019. V. 59. Iss. 1. P. 86-98. DOI:

$10.1134 / \mathrm{S} 0001437019010168$

16. Удовик В.Ф., Харитонова Л.В., Горячкин Ю.Н. Мониторинг состояния городских пляжей Севастополя // Экологическая безопасность прибрежной и шельфовой зон моря. 2017. Вып. 4. С. 86-94. 17. Алемов С.В., Витер Т.В., Гусева Е.В. Многолетние изменения состояния сообществ макрозообентоса бухты Круглая (регион Севастополя) // Экологическая безопасность прибрежной и шельфовой зон моря. 2019. Вып. 2. C. 59-66. DOI: 10.22449/2413-5577-2019-259-66

18. Калугина-Гутник А.А. Фитобентос Черного моря. К.: Наукова думка, 1975. 248 с.

19. Мильчакова Н.А., Миронова Н.В., Рябогина В.Г. Морские растительные ресурсы // Промысловые биоресурсы Черного и Азовского морей. Севастополь, 2011. Гл. 4. С. 117-139.

20. Максимова О.В., Лучина Н.П. Современное состояние макрофитобентоса у побережья северного Кавказа: реакция фитали на эвтрофикацию черноморского бассейна // Комплексные исследования северо-восточной части Черного моря. М.: Наука, 2002. C. 297-308.

21. Миничева Г.Г., Большаков В.Н., Калашник Е.С., Зотов А.Б., Маринец А.В. Оценка реакции альгосообществ черноморских экосистем на воздействие климатических факторов // Альгология. 2018. Т. 28. N 2. C. 121-135. DOI: $10.15407 /$ alg28.02.121

22. Миронова Н.В., Мильчакова Н.А., Александров В.В. Тенденции долговременного изменения запасов макрофитов в бухте Казачья (Крым, Черное море) // Морской экологический журнал. 2012. Т. ХІ. N 3. С. 6878.

23. Доценко С.Ф., Иванов В.А. Катастрофические природные явления Азово-Черноморского региона. Севастополь: Морской гидрофизический институт, 2013. 193 c.

\section{REFERENCES}

1. Krasnaya kniga Respubliki Krym. Rasteniya, vodorosli i griby [Red Book of the Republic of Crimea. Plants, algae and mushrooms]. Simferopol, OOO IT ARIAL Publ., 2015, 480 p. (In Russian)
2. Dumont H. J. (Ed.). Black Sea Red Data Book. NY, United Nations Office for Project Services, 1999, 413 p. 3. Krasnaya kniga Rossiiskoi Federatsii (rasteniya i griby) [Red Book of the Russian Federation (Plants and Mushrooms)]. Moscow, KMK Publ., 2008, 885 p. (In Russian)

4. Krasnaya kniga Sevastopolya [Red Book of Sevastopol]. Kaliningrad, «ROST-DOAFK» Publ., 2018, 432 p. (In Russian) 5. Council Directive 92/43/EEC of 21 May 1992 on the conservation of natural habitats and of wild fauna and flora. URL:

http://eurlex.europa.eu/LexUriServ/LexUriServ.do?uri=CEL EX:31992L0043:EN:html (accessed 19.04.2019)

6. Zernov S.A. To the question of studying the life of the Black Sea. Zapiski Imperatorskoi Akademii Nauk [Notes of the Imperial Academy of Sciences]. 1913, vol. 32, no. 1, 304 p. (In Russian)

7. Kalugina-Gutnik A.A, Evstigneeva I.K., Mironova N.V. Changes in bottom vegetation on the open coast of Sevastopol Bay for the period from 1964 to 1990. Algologia, 1993, vol. 3, no. 2, pp. 42-48. (In Russian) 8. Evstigneeva I.K., Nikolenko N.V. Vegetation of the coastal shallow waters of the Black Sea under anthropogenic impact. Al'gologiya [Algology]. 2003, vol. 13, no. 4, pp. 371-380. (In Russian)

9. Kovardakov S.A., Prazukin A.V. Structural and functional characteristics of the bottom seaweeds community in Kruglaya Bay (Sevastopol). Ekosistemy, ikh optimizatsiya i okhrana [Optimization and Protection of Ecosystems]. 2012, no. 7, pp. 138-148. (In Russian)

10. Guryanova E.F. [The theoretical basis for the mapping of underwater landscapes]. In: Voprosy ' biostratigrafii kontinental'ny`x tolshh [Questions of biostratigraphy of continental strata]. Moscow, 1959, pp. 35-48. (In Russian) 11. Lindberg G.U. Kartirovanie podvodnykh landshaftov $\mathrm{s}$ tsel'yu izucheniya zakonomernostei raspredeleniya zhivotnykh [The mapping of underwater landscapes to study patterns of animal distribution]. Trudy III sessii Vsesoyuznogo Paleontologicheskogo obshchestva "Voprosy biostratigrafii kontinental'nykh tolshch", Moskva, 1959 [Proceedings of the III session of the AllUnion Paleontological Society "Problems of biostratigraphy of continental strata", Moscow, 1959]. Moscow, Gosgeoltekhizdat Publ., 1959, pp. 49-52. (In Russian) 12. Petrov K.M. Podvodnyye landshafty: teoriya, metody issledovaniya [Underwater Landscapes: Theory, Research Methods]. Leningrad, Nauka Publ., 1989, 126 p. (In Russian)

13. Mironova N.V., Pankeeva T.V. The spatial distribution of macrophytobenthos taking into account the landscape structure of the south-western part of the region of Sevastopol. Ekosistemy [Ecosystems]. 2018, no. 14 (44), pp. 20-30. (In Russian)

14. Mironova N.V., Pankeeva T.V. Long time changes of spatial distribution of phytomasses stock of seaweeds in the Laspi Bay (The Black Sea). Ekosistemy [Ecosystems]. 2018, no. 16 (46), pp. 33-46. (In Russian)

15. Pankeeva T.V., Mironova N.V. Spatiotemporal changes in the macrophytobenthos of laspi bay (Crimea, Black Sea) Oceanology, 2019, vol. 59, iss. 1, pp. 86-98. DOI:

10.1134/S0001437019010168

16. Udovik V.F., Kharitonova L.V., Goryachkin Yu.N. Monitoring of the urban beaches of Sevastopol. 
Ekologicheskaya bezopasnost' pribrezhnoy i shel'fovoy zon morya [Ecological safety of the coastal and shelf zones of the sea]. 2017, iss. 4, pp. 86-94. (In Russian)

17. Alyomov S.V., Viter T.V., Guseva E.V. Long-term changes of the state of macrozoobenthos comuninies in Kruglaya Bay (Sevastopol). Ecological safety of the coastal and shelf zones of the sea, 2019, iss. 2, pp. 59-66. (In Russian) DOI: 10.22449/2413-5577-2019-2-59-66

18. Kalugina-Gutnik A.A. Fitobentos Chernogo morya [Phytobenthos Black Sea]. Kyiv, Naukova Dumka, 1975, 248 p. (In Russian)

19. Milchakova N.A., Mironova N.V., Ryabogina V.G. [Marine plant resources]. In: Promyslovye bioresursy Chernogo i Azovskogo morei [Commercial bioresources of the Black and Azov Seas]. Sevastopol, Ekosi-Gidrofizika Publ., 2011, no. 4, pp. 117-139. (In Russian) 20. Maximova O.V., Luchina N.P. [Modern state of macrophytobenthos off the Northern Caucasian coast: a response to eutrophication of the Black Sea basin]. In:

\section{КРИТЕРИИ АВТОРСТВА}

Миронова Н.В. принимала участие в сборе и обработке материалов в 1977 и 2018 гг. Автором проанализированы пространственно-временные изменения макрофитобентоса. Панкеева Т.В. принимала участие в морской экспедиции по сбору первичного материала и его обработке в 2018 гг. Автором составлены ландшафтные карты, дан анализ пространственно-временных изменений ландшафтной структуры дна. Все авторы в равной степени несут ответственность при обнаружении плагиата, самоплагиата или других неэтических проблем.

\section{КОНФЛИКТ ИНТЕРЕСОВ}

Авторы заявляют об отсутствии конфликта интересов
Kompleksnyye issledovaniya severo-vostochnoy chasti Chernogo moray [Studies of complexes of the northeastern part of the Black Sea]. Moscow, Nauka Publ., 2002, pp. 297-308. (In Russian)

21. Minicheva G.G., Bolshakov V.N., Kalashnik E.S., Zotov A.B., Marinets A.V. Assessment of the reactions of the Black Sea ecosystem's algaecommunities to influence of climatic factors. Algologia, 2018, vol. 28, no. 2, pp. 121135. (In Russian) DOI: 10.15407/alg28.02.121

22. Mironova N.V., Milchakova N.A., Alexandrov V.V. Trends in long-term changes of macrophite resourses in the Kazachya Bay (Sevastopol, Crimea, Black Sea). Morskoy ekologicheskiy zhurnal [Marine Ecological Journal]. 2012, vol. XI, no. 3, pp. 68-78. (in Russian)

23. Dotsenko S.F., Ivanov V.A. Katastroficheskiye prirodnyye yavleniya Azovo-Chernomorskogo regiona [Catastrophic Natural Phenomena of the Azov-Black Sea Region]. Sevastopol, Marine Hydrophysical Institute Publ., 2013, 193 p. (In Russian)

\section{AUTHOR CONTRIBUTIONS}

Nataliya V. Mironova participated in the collection and processing of materials in 1977 and 2017-2018 and analysed the spatio-temporal changes of the macrophytobenthos. Tatyana V. Pankeeva participated in the collection and processing of materials in 20172018, drew up landscape maps and analysed the spatiotemporal changes in the seascape structure. All authors are equally responsibility for plagiarism, self-plagiarism and other ethical transgressions.

\section{NO CONFLICT OF INTEREST DECLARATION}

The authors declare no conflict of interest.

ORCID

Наталия В. Миронова / Nataliya V. Mironova http://orcid.org/0000-0001-7110-7081

Татьяна В. Панкеева / Tatyana V. Pankeeva http://orcid.org/0000-0002-8933-6103 